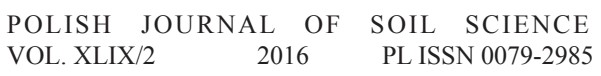

DOI: $10.17951 / \mathrm{pjss} / 2016.49 .2 .123$

AGNIESZKA MOCEK-PŁÓCINIAK*

\title{
RECLAMATION AND DEVELOPMENT OF GEOMECHANICALLY TRANSFORMED LAND IN THE KONIN-TUREK COAL BASIN
}

\begin{abstract}
This overview article presents major forms of reclamation and development of external and internal spoil tips, which are formed during brown coal mining and from bottom ash dumped near open-pit mines and power stations. In the late 1970s, a new form of agricultural and forest recultivation was developed - the PAN model. According to the concept, crops and forest-forming plant species should be introduced to post-mining grounds immediately after the end of technical recultivation. Vegetation is a particularly reliable indicator of habitat properties and small changes taking place in nature undergoing recovery. Other bioindicators of the quality and health of newly formed soil include the biomass of microorganisms, their count, composition and enzymatic activity. In many countries the assessment of the influence of anthropogenic stress factors on the count of soil microorganisms has become one of key elements of obligatory inspection under environmental monitoring. In consequence of revitalisation of anthropogenically changed areas, biological life is restored within the period of at least 20-30 years. It is manifested by the development of microbial population and soil fauna.
\end{abstract}

Keywords: reclamation, post-mining areas, enzymatic activity, microorganisms, vegetation

\section{INTRODUCTION}

Many minerals are acquired by means of open-pit or underground mining. It causes land transformation and permanent changes in the landscape. New convex forms known as external spoil tips appear in natural geomorphological systems. They contain deposits of waste rocks, which are extracted together

* Department of Microbiology, University of Life Sciences in Poznań. 
with minerals. Spoil tips are often accompanied by concave forms, i.e. borrow pits, when different raw materials are extracted by open-pit mining.

In Poland the area of geomechanically transformed land encompasses about 60,000 ha (Central Statistical Office 2011). The largest areas of degraded and devastated land can be found in Greater Poland Voivodeship (9,600 ha), Lower Silesian Voivodeship (6,000 ha) and Silesian Voivodeship (4,400 ha) (Karczewska 2012). In Greater Poland Voivodeship geomechanical transformations were chiefly caused by extraction of brown coal. The transformations can mostly be found in the former Konin Voivodeship, where the Konin-Turek Coal Basin enterprises have been operating for several decades. According to the Farmland and Forest Protection Act, areas transformed by anthropogenic activity are classified as degraded or devastated land and should be recultivated and appropriately developed.

Owing to Prof. Skawina, who started the Polish recultivation school, in the past the concept of recultivation was interpreted as giving or restoring utility or natural values in areas destroyed by human activity. Recultivation consists in appropriate formation of the land relief by improvement of its physiochemical properties, adjustment of air-water relations, strengthening of scarps, reconstruction of the hydrographic network, if possible, and construction of necessary roads. According to Gilewska (1991), recultivation is a complex of engineering and agrotechnical procedures as well as biogeochemical processes, which are conducted in order to develop a new, desirable biocenotic structure of industrial technosol. This deliberate interaction of biotic and abiotic factors should result in formation of living soil from the original barren post-mining land in the shortest time possible (10-15 years).

Recultivation is a complex procedure and it depends on the type of land degradation. As far as the processes of geomechanically or hydrologically transformed land or soil are concerned, the new term 'revitalisation' is used increasingly often. When the soil profile is not completely or partially destroyed, but there are significant changes in the chemical properties of the pedon only (salinity, acidity, higher content of mineral and organic xenobiotics), the procedures applied in order to improve these properties, i.e. the elimination or limitation of the influence of pollutants, are defined as soil remediation.

This overview article gives a synthetic presentation of major forms of recultivation and development of external and internal spoil tips, which are formed during brown coal mining and from bottom ash dumped near open-pit mines and power stations. 


\section{BROWN COAL IN THE GREATER POLAND REGION AND RECULTIVATION OF SPOIL TIPS}

Brown coal in the Konin-Turek Coal Basin is extracted by means of openpit mining. At least two years before the first excavation it is necessary to make a drainage barrier around the planned borrow pit. Next, the overburden covering the mineral is removed and deposited next to the opening excavation. It forms an external spoil tip. Overburdens from consecutive outcrops are usually heaped in disused borrow pits, thus making internal spoil tips. Due to the lack of material to be deposited in the last borrow pit in a planned sequence of outcrops, this place is usually used as a water reservoir for tourist and recreational purposes. Clarifiers of ash from power stations are sometimes placed in end borrow pits.

Spoil tips are mostly composed of Quaternary and Neogene bedrocks (Spychalski et al. 2016). These are mainly glacial loams of the Warthe stage and Vistulian glaciation, Quaternary sands and partly Poznań clays and Miocene sands. Spoil tips have different mixtures of these bedrocks. These post-mining grounds usually have relatively good granulometric and mineralogical composition, alkaline or neutral $\mathrm{pH}$ due to the presence of calcium carbonates, average potassium abundance and specific organic matter represented by the admixture of brown coal (Gilewska and Otremba 2007; Gilewska 2008; Otremba and Gilewska 2013).

There are five trends in post-mining land recultivation in the KoninTurek Coal Basin, i.e. forest, agricultural, water, recreational-tourist and special. Table 1 shows the areas subjected to individual trends of recultivation and development in the Konin-Turek Coal Basin.

TABLE 1. AREAS DEVELOPED IN DIFFERENT WAYS IN THE KONIN-TUREK COAL BASIN (KASZTELEWICZ 2010).

\begin{tabular}{cccccc}
\hline \multirow{2}{*}{ Mine name } & \multicolumn{5}{c}{ Development trends (ha) } \\
\cline { 2 - 6 } & Agricultural & Forest & Water & Others & Total \\
\hline $\begin{array}{c}\text { Adamów Mine } \\
\text { in Turek }\end{array}$ & $2,161.1$ & 615.8 & 894.2 & 21.9 & $3,693.0$ \\
\hline $\begin{array}{c}\text { Konin Mine in } \\
\text { Kleczew }\end{array}$ & $3,909.0$ & $2,402.0$ & 596.0 & $\begin{array}{c}861.0 \text { (including } \\
160.0 \text { of recreational } \\
\text { development) }\end{array}$ & $7,768.0$ \\
\hline Total & $6,070.1$ & $3,017.8$ & $1,490.2$ & 882.9 & $11,431.0$ \\
\hline
\end{tabular}

External spoil tips are chiefly subjected to forest recultivation. After the end of technical recultivation (hilltop levelling, scarp formation, etc.) biological recultivation begins. It consists of individual stages, which will be described later in this article.

Agricultural recultivation is chiefly carried out on internal spoil tips, which are formed in relation to the original ordinate of the area. Similarly to forest recul- 
tivation, different methods of agricultural recultivation and development of these areas were used in the past. More information can be found later in this article.

According to the data in Table 1, the largest part of land which was anthropogenically transformed by brown coal extraction in the Greater Poland region was subjected to agricultural and forest recultivation. Initially, in the 1960s and 1970s, the method of biological soil recovery was used. It was invented by Prof. Skawina. Vegetation was the main soil-forming factor, which transformed barren rock (post-mining grounds) into a living form of soil. According to the assumptions of this concept, defined as the pioneer vegetation concept, the process of soil formation in the post-mining bedrock is initiated by long-term cultivation of herbaceous plants, especially melilot, in agricultural recultivation, and by tree planting, mostly black locusts, black and grey alders. This pioneer vegetation remains in place for 4-7 years if land is subjected to agricultural recultivation or for 10-15 years if it is subjected to forest recultivation (Kasztelewicz 2010). After that, the pioneer vegetation must be replaced by new, economically useful plants. Prof. Skawina mostly promoted forest recultivation. In his opinion, it should be the main trend in the recultivation and development of areas affected by anthropogenic impact on the environment in Poland.

In the 1980s, Prof. Krzaklewski (1988) proposed the biodynamic recultivation method. It chiefly applied to forest recultivation. According to this method, afforestation should be preceded by hydroseeding or air hydroseeding of herbaceous plants. A mixture of grasses and leguminous plants (large-leaved lupine, common bird's-foot trefoil, white and red clover, red fescue, black bent) should be sown at an amount of $40-60 \mathrm{~kg} \cdot \mathrm{ha}^{-1}$ with $20-30 \mathrm{Mg} \cdot$ ha- 1 of sewage sludge. In the beginning, vegetation protects the soil surface from erosion. After that, a tree stand consisting of afforesting (75\%), phytomelioration (20\%) and biocenotic $(5 \%)$ species is brought to the biologically recovered surface.

In the late 1970s, a new concept of agricultural and forest recultivation was developed - the PAN model. The scientific basis of the concept, aka the target species method, was invented by the Poznan school headed by Prof. Bender $(1979,1981)$ and developed by his students Prof. Gilewska and Dr hab. Otremba (PhD). According to the concept, crops (agricultural recultivation) and afforesting plant species (forest recultivation) should be introduced to post-mining grounds immediately after the end of technical recultivation. There are four basic rules in the concept:

- repair of the chemical properties of the post-mining ground (parent materials) by adequately high mineral fertilisation, determined by the physiochemical parameters of the ground, its retention capacity and plant recultivation requirements;

- repair of the physical properties of the ground by adequate mechanical cultivation, leading to homogenisation of the heterogeneous and polydisperse mass of Quaternary and Neogene formations; 
- $\quad$ selection of crops and afforesting plants. According to the concept, all plants can be used, but the preferable crops are: cereals, rapeseed and alfalfa, and the preferable afforesting plants are: oak, ash, larch and pine trees;

- $\quad$ adequate technical (basic) recultivation, i.e. hilltop and scarp formation, construction of hydrological and road networks, etc.

The advantages of this common concept of development of post-mining spoil tips are: relatively quick (10-15 years) transformation of post-mining grounds into soil and rapid production of useful biomass. Fig. 1 shows the scheme of this concept.

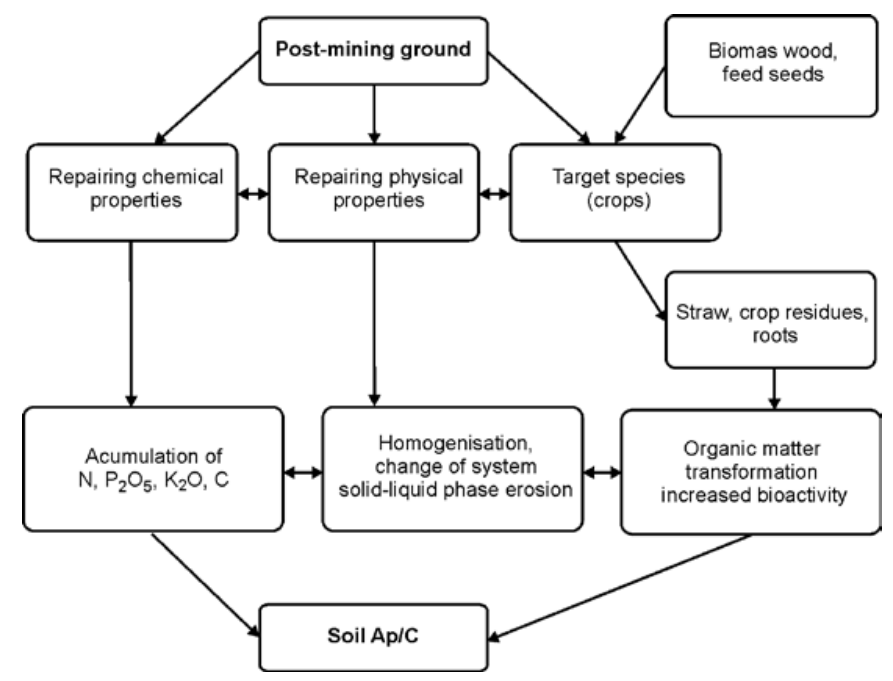

FIG. 1. A GRAPHIC PRESENTATION OF THE TARGET PLANT CONCEPT - THE PAN MODEL (SPYCHALSKI ET AL. 2016).

According to the Polish Soil Classification (PSC 2011), soils formed from post-mining grounds belong to the class of anthropogenic soils, with low content of organic matter and rainfall water management. These factors strongly limit their productivity. The rooting rate and yield of crops and afforestation plants mostly depends on the amount of rainfall and its distribution during the vegetation season. This factor is a chief limitation to the effects of recultivation and development in the Greater Poland region.

\section{BIOLOGICAL RECULTIVATION OF POWER STATION ASH DUMPS}

Brown coal extracted in the Konin-Turek Coal Basin (about 10-12 million $\mathrm{Mg}$ a year) is mostly used as a source of energy for power stations belonging to the Pątnów-Adamów-Konin Power Plants. By burning this cheapest energy car- 
rier non-combustible mineral components are produced, which are energy waste products. They are classified according to the size of grains as follows:

- $\quad$ fly ash - these are remains left after coal combustion in power boilers, accumulated in dedusting units (filters) in power plants with dust furnaces (burnt ground coal) or smokebox ash - these are remains left in power boilers with gridiron furnaces;

- $\quad$ slag - these are remains of coal combustion fallen to the bottom of the furnace or left on the gridiron.

These waste products are often used as recyclable materials (Rosik-Dulewska 2015) or they are stored at industrial waste dumps. In the Konin-Turek Coal Basin there are dry and wet dumps of ash from power plants. An ash spoil tip in close neighbourhood of the Adamów Power Plant in Turek, which has been recultivated by afforestation, is an example of a dry ash dump.

For many years this external dump was not properly recultivated. The biological recultivation of accumulated waste was difficult due to its high susceptibility to erosion as well as particularly unfavourable water and chemical properties (alkaline $\mathrm{pH}$, salinity, lack of many macro- and microelements). In the 1970s, the place was successfully recultivated by afforestation based on the PAN model. An oasis of vegetation developed on the dump by planting many tree and shrub species, such as: black locust, Norway maple, black alder, red oak, salt cedar, five-stamen tamarisk, black cherry, senjed, sea buckthorn, etc.

At present, most waste from power stations is stored in former borrow pits, where material is transported hydraulically in the form of pulp. These are wet dumps. Recultivation work is done in land parts of these dumps. It is based on the results of experimental plots, which were established to repair the chemical properties of clean ash deposits or deposits of ash mixed with a layer of sewage sludge with grey glacial clay and appropriate mineral fertilisation (NPK or N).

The most common plants grown on these waste dumps are: green ash, Norway maple, boxelder maple, black locust, senjed, Siberian peashrub and sea buckthorn. The root rate of applied treatments was diversified and depended on many natural factors: the age of the dump, degree of ash erosion, the size of ash grains and their physiochemical parameters as well as clay or sewage sludge fertilisation. In order to achieve satisfactory results of these difficult undertakings it is necessary to take care of recultivated areas regularly and to monitor the recovering biological life in this mineral waste.

\section{THE INFLUENCE OF VEGETATION AND MICROORGANISMS AS FACTORS AND INDICATORS OF BIOLOGICAL RECULTIVATION}

As was mentioned above, vegetation matching the area subjected to recultivation plays a particularly important role as a soil-forming factor. The root system penetrates deep inside, pushing and crushing various waste products. 
In consequence, smaller aggregates of deposited material are formed. Apart from that, dead root systems leave capillaries that enable gas exchange. The soil structure is positively influenced by plants with the bundle root system, e.g. cereals. The role of soil microorganisms is also important in structure-forming processes. They participate in organic matter transformation processes and produce binding compounds. The resultant wax, pitch, fat or rubber facilitate aggregation significantly and by saturation aggregates become more resistant to water. In consequence, the susceptibility of soil to crusting is reduced (Otremba 2011). Mixtures of leguminous plants and grasses are also used in biological recultivation. They form compact turf and prevent erosion (Karczewska 2008; Mocek-Płóciniak 2014). Apart from that, they have numerous favourable qualities in terms of their capacity to recover the humus layer and restore bioactivity. White melilot is particularly useful for the recultivation of post-mining land and industrial wasteland all over Europe (Bender and Gilewska 2004). Due to minimal nutritional requirements and symbiosis with rhizobia and actinobacteria, black locust, black alder, grey alder and Siberian peashrub do not need additional nitrogen fertilisation. They use atmospheric nitrogen from symbiotic organisms (Karczewska 2012). Apart from that, they produce large aerial mass, which is an important source of organic matter for the recovered humus layer. These plants also have large mass of roots. The draining root system of alfalfa, which goes deep into the ground, enables the uptake of water and nutrients even under extremely adverse weather conditions (Karczewska 2008). Thus, vegetation is a particularly reliable indicator of habitat properties and small changes taking place in nature which is undergoing recovery (Nietrzeba-Marcinonis and Górecki 2009).

Enzymatic activity is another sensitive indicator of the biological state of recultivated land. It provides information about normal metabolism in soil (Bielińska and Tomaszewicz 2006; Bielińska and Mocek-Płóciniak 2009; Bielińska et al. 2014; Kuczyńska 2003; Mocek-Płóciniak 2014; Collective work edited scientifically by Andrzej Mocek 2015). Investigations of enzymatic activity give a possibility to register changes in the specific capacity of the soil complex caused by anthropogenic stress (Kieliszewska-Rokicka 2001). Apart from that, soil enzymes actively participate in metabolism and catalyse soil-forming processes by processing organic matter and energy (Baran 2000). Changes in soil enzymatic activity are the earliest signal of changes in the intensity of vital processes in the environment (Bielińska and Pranagal 2006). Without the need to identify many compounds, these bioindicators also illustrate the scale of soil contamination caused by natural and anthropogenic environmental factors, which significantly endanger living organisms (Collective work edited scientifically by Andrzej Mocek 2015). Enzymes determining respiratory processes and hydrolytic enzymes are reliable indicators of the state of soil under formation (Kucharski 1997). They are natural catalysts of many important environmen- 
tal processes. They participate in the circulation of bio-elements, synthesis and decomposition of humus. They release mineral substances and provide them to plants. They bind molecular nitrogen, detoxify xenobiotics and are responsible for nitrification and denitrification (Russel 2005). Other bioindicators of the quality and health of newly formed soil include the biomass of microorganisms, their count, composition and respiratory activity. In many countries, the assessment of the influence of anthropogenic stress factors on the development and activity of soil microorganisms has become one of key elements of obligatory inspection under environmental monitoring (Collective work edited scientifically by Andrzej Mocek 2015). Apart from microorganisms, underground parts of plants and the soil fauna are other sources of soil enzymes. Post-mining grounds and industrial waste are characterised by very low bioactivity or its complete absence (Gilewska and Płóciniczak 2004; Gilewska and Płóciniczak 2007; Karczewska 2008). As the process of recultivation progresses, there is greater diversity and count of organisms per ground volume unit. Usually, it is manifested by the increasing soil biocenosis capacity to transform carbon, nitrogen and phosphorus compounds (Karczewska 2008). In consequence of revitalisation of anthropogenically changed areas, biological life is restored within the period of at least 20-30 years, which is manifested by the growth and development of microbial population and soil fauna.

\section{CONCLUSIONS}

Soil is the most durable component of the natural environment but it is also the most difficult to restore. Naturally, this process may last a few decades or even centuries. By contrast, soil degradation may occur at a one hundred faster rate (Nietrzeba-Marcinonis and Górecki 2009). Devastated and degraded areas need recultivation and careful development. It is always necessary to take an individual approach to each case of land recultivation. The best solutions require long-term and costly research and cooperation of many experts in different branches. It is a difficult interdisciplinary problem. Appropriate recultivation works guarantee transformation of industrial waste dumps and land into new forest and agricultural habitats or water, sports and recreational facilities of adequately high ecological and economic values. Successful remedial treatments may additionally increase the attractiveness of new surroundings (Kasztelewicz et al. 2007; Kasztelewicz 2010; Kasztelewicz and Sypniowski 2010; Mocek-Płóciniak 2014; Nietrzeba-Marcinonis 2010; Orlikowski and Szwed 2011). After some time biodiversity develops in the recultivated land or waste. The populations of basic groups of soil microorganisms increase. In consequence, they improve edaphic properties, which determine the physiochemical parameters of a newly formed soil cover. 


\section{REFERENCES}

[1] Baran, S., 2000. An Assessment of the State of Soil Degradation and Recultivation. A Guide for Classes (in Polish). Wyd. AR, Lublin.

[2] Bender, J., 1979. Post-Mining Recultivation - a Case Study of a Mine in the Konin Brown Coal Basin (in Polish). Komitet PAN “Człowiek i Środowisko”, Warsaw, 156-184.

[3] Bender, J., 1981. Developing the Productivity of Industrial Soils by Agricultural and Forest Recultivation (in Polish). Typescript, JPIŚ PAN, Zabrze, 39 pp.

[4] Bender, J., Gilewska, M., 2004. Recultivation in the Light of Investigations and Implementations (in Polish). Rocz. Glebozn., 2, 29-46.

[5] Bielińska, E.J., Pranagal, J., 2006. Enzymatic Activity as an Indicator of Degradation of Silt Soils Used for Farming (in Polish). Rocz. Glebozn., 56, 1/2: 41-49.

[6] Bielińska, E.J., Tomaszewicz, T., 2006. The Influence of Anthropogenic Factors on the Enzymatic Activity of Roadside Soils (in Polish). Rocz. Glebozn., LVII, 1/2, Warsaw, 50-58.

[7] Bielińska, E.J., Mocek-Płóciniak, A., 2009. Phosphatases in the Soil Environment (in Polish). Wyd. UP, Poznań.

[8] Bielińska, E.J., Futa, B., Mocek-Płóciniak, A., 2014. Soil Enzymes as Bioindicators of Soil Quality and Health (in Polish). Wyd. Librepolis, Lublin.

[9] Dz.U. ( Journal of Laws), 3 February 1995. Farmland and Forest Land Protection (in Polish). Dz.U. ( Journal of Laws) 2013 Pos. 1205.

[10] Gilewska, M., 1991. Biological Recultivation of Post-Mining Land - a Case Study of the Brown Coal Mine in Konin (in Polish). Roczn. AR w Poznaniu, Rozprawy Naukowe, 211.

[11] Gilewska, M., Otremba K., 2007. Organising Production Space in Post-Mining Land a Case Study of the Brown Coal Mine in Konin (in Polish). Górnictwo odkrywkowe, 5-6.

[12] Gilewska, M., 2008. The Morphogenetic Activity of Open-Pit Mining Around Konin and Turek (in Polish). Rocz. Glebozn., LIX, 2, Warsaw, 48-55.

[13] Gilewska, M., Płóciniczak, A., 2004. Enzymatic Activity in Ash Landfills. 11th International Conference 'Ash from the Power Industry' (in Polish), 13-16 October, Zakopane, 299-305.

[14] Gilewska, M., Płóciniczak, A., 2007. Alkaline Phosphatase Activity in Soils Developing from Post-Mining Land (in Polish). Inżynieria Środowiska, 13, Zeszyty naukowe,133: 118-126.

[15] GUS (in Polish) (Central Statistical Office) 2011. Statistical Yearbook. Główny Urząd Statystyczny, Warsaw.

[16] Karczewska, A., 2008. Soil Protection and Recultivation of Degraded Areas (in Polish). Wyd. UP, Wrocław.

[17] Karczewska, A., 2012. Soil Protection and Recultivation of Degraded Areas (in Polish). Wyd. UP, Wrocław, $390 \mathrm{pp}$.

[18] Kasztelewicz, Z., Kozioł, K., Klich, J., 2007. Recultivation of Post-Mining Areas in Brown Coal Mines in Poland (in Polish). Górnictwo i Geoinżynieria, 31, 2: 295-307.

[19] Kasztelewicz, Z., 2010. Recultivation of Post-Mining Areas in Polish Open-Pit Mines (in Polish). Fundacja Nauka i Tradycje Górnicze z siedzibą Wydział Górnictwa i Geoinżynierii Akademii Górniczo-Hutniczej im. Stanisława Staszica w Krakowie (The Science and Mining Traditions Foundation seated at the Faculty of Mining and Geoengineering, Stanisław Staszic AGH University of Science and Technology in Kraków). Monograph: 464 pp.

[20] Kasztelewicz, Z., Sypniowski, Sz., 2010. Open-Pit Mining vs Recultivation of Post-Mining Areas. Part 2. Ecological Problems (in Polish), 14,2: 74-84.

[21] Kieliszewska-Rokicka, B., 2001. Soil Enzymes and Their Significance to Investigations of Soil Microbial Activity (in Polish). In: Microorganisms in the Soil Environment - Physiological, Biochemical and Genetic Aspects. Ed. H. Dahm, A. Pokojska-Burdziej, UMK, Toruń, 37-47.

[22] Krzaklewski, W., 1988. Forest Recultivation and Biological Handling of Post-Industrial Wasteland (in Polish). AR, Kraków, 108 pp. 
[23] Kucharski, J., 1997. Relations Between Enzymatic Activity and Soil Fertility (in Polish). Conference proceedings 'Microorganisms in the Environment'. AR, Kraków, 349-356.

[24] Kuczyńska, L., 2003. The Count of Microorganisms and Enzymatic Activity of Soil Contaminated with Coal Ash (in Polish). Rocz. Glebozn., LIV, 1/2, Warsaw, 99-106.

[25] Mocek-Płóciniak, A., 2014. Biological Recultivation of Land Degraded by Brown Coal and Copper Ore Mining (in Polish). Nauka Przyr. Techno., 8, 3, \#42.

[26] Nietrzeba-Marcinonis, J., Górecki, R., 2009. Creation of a Forest Ecosystem in Consequence of Recultivation Works (in Polish). Symposium Proceedings, 246-256.

[27] Nietrzeba-Marcinonis, J., 2010. Biological Recultivation of Post-Mining Land at the PGE Brown Coal Mine Turów S.A.(in Polish). Górnictwo i Geoinżynieria, 34, 4: 435-443.

[28] Orlikowski, D., Szwed, L., 2011. Developing Post-Mining Land at the Brown Coal Mine 'Adamów' S.A. in Turek - Pre-Mining and Post-Mining Landscape (in Polish). Górnictwo i Geoinżynieria, 35, 3: 225-240.

[29] Otremba, K., 2011. The Role of Vegetation in Forming Basic Physical Properties of Soils Developing from Post-Mining Land (in Polish). Nauka Przyr. Techno., 5, 6, \#109.

[30] Otremba, K., Gilewska, M., 2013. The Mineralogical Composition of Post-Mining Land and Soils Developing from This Parent Material (in Polish). Inżynieria Środowiska, 30, Uniwersytet Zielonogórski, Zeszyty Naukowe, 150: 34-42.

[31] Collective work edited scientifically by Andrzej Mocek, 2015. Gleboznawstwo, PWN, Warsaw.

[32] PSC (The classification of Polish soils). 2011. Soil Science Annuall, XII, 3.

[33] Rosik-Dulewska, Cz., 2015. The Essentials of Waste Management (in Polish), PWN, Warsaw.

[34] Russel, S., 2005. The Significance of Enzyme Investigations in the Soil Environment (in Polish). Acta Agrophys. Elaboration and Monograph, (3): 5-9.

[35] Spychalski, W., Mocek, A., Gilewska, M., Owczarzak, W., Otremba, K., 2016. The Possibilities of Recultivation and Agricultural Use of Post-Mining Land-a Case Study of the Experiment Conducted on the Spoil Tip of the Open-Pit Brown Coal Mine 'Patnów' (in Polish), Wyd. UP, Poznań. 